Light, therefore, has a dual character. It consists of electrical waves and the quantum. The electrical waves give rise to interference effects and the quantum to photo-electric effects. The energy in the electrical waves surrounding the quantum does not alter as the system travels through space, and so the ratio of the energy in these waves and that in the quantum remain invariable. The mathematical proofs based on the theory of probability given in this paper are very neat and very easy to understand.

In a paper read before the Royal Society of Edinburgh on February 8, Prof. E. T. Whittaker follows up Sir J. J. Thomson's paper and shows that the Maxwell-Lorentz equations can easily be modified so as to represent Sir Joseph's ideas regarding light. What distinguishes Thomson's theory from the work of all other writers on the subject is that he pictures the structure of the light-quanta in terms of tubes of electric force. When light is generated he invites us to picture a closed part of a loop in a tube of electric force to become detached and go off as a closed ring. This ring soon becomes circular and travels with the velocity of light in a direction at right angles to its plane, like a circular vortex ring. The energy of the ring remains constant until the ring is broken.
It is known, for example, that if cathode rays fall on a metallic plate and generate $\mathrm{X}$-rays which fall on a second metallic plate, electrons are ejected from the second plate and their energy is of the same order as that of the electrons in the primary cathode rays and is independent of the distance of the plates.

The only explanation seems to be that the energy of the X-rays is contained in compact parcels between the plates. This phenomenon has led Einstein and other physicists to advocate corpuscular theories of light. In Thomson's theory we picture something similar to a procession of rings of cigarette smoke, moving forward through the air in front of the mouth of a smoker. As the group moves through space, it sweeps over the interior of an infinitely long, straight cylinder, the axis of which is in the direction of propagation. Everywhere outside this cylinder the field is permanently null.

Sir Joseph points out that it is not necessary to suppose that light consists exclusively of a procession of 'electric vortex rings.' $\mathrm{He}$ considers that it consists of rings of electric force accompanied by Maxwellian waves. These rings sometimes vibrate and produce waves of the type ordinarily considered. Whittaker gives a justification of Thomson's hypothesis and a verification of the quantum relation.

\title{
Salient Features in the Stratigraphy, Tectonic Structure, and Physiography of the Commonwealth of Australia. ${ }^{1}$
}

A BRIEF summary of the salient features of the stratigraphy of the Commonwealth is essential for understanding its tectonic structure. Pre-Cambrian rocks are developed in Western, Central, and South Australia. The Proterozoic rocks of Northern Australia are partly formed of thick dolomites, possibly a forerunner of the Great Barrier Reef of to-day. Basic lavas and tuffs, 3000 feet thick, preceded a great ice-age in late Proterozoic or early Cambrian time. Marine Cambrian strata occur chiefly in Northern and Central Australia and South Australia, with patches in Victoria, Tasmania, and Queensland. Ordovician rocks attain a thickness of 40,000 feet in Victoria and Central Australia. Igneous intrusions and unconformity separate the Ordovician rocks from the Silurian. In the Devonian rocks of Queensland, coralline limestone, 7000 feet thick, is probably another ancestor of the Great Barrier Reef. In Carboniferous time a south-eastern shore of 'the Tethys Sea ' is well defined in the northwest of Western Australia. Carboniferous and Devonian time were periods of granitic intrusions and effusive rocks. In Permo-Carboniferous time half Australia was under ice. This was the chief coal-forming epoch, followed by more coal (in Triassic and in Jurassic times) developed in immense epicontinental lakes in eastern and central Australia, near which carnivorous deinosaurs existed.

Marine Jurassic strata in Australia are only found in 'the Tethys Sea' of Western Australia. The great dolerite-sills (comparable with the Karroo dolerites) of Tasmania possibly closed Jurassic time. Cretaceous time witnessed great peripheral and central marine transgressions. The Neocomian Sea was probably cold, and epeirogenic uplift in east Central Australia replaced marine by lacustrine conditions; this uplift was probably accompanied by small local glaciation. In Western Australia the last of "the 'Tethys Sea' is represented by the Lower Santonian with Uintacrinus (comparable with the Arriloor Beds of Southern India). Cretaceous strata were slightly

I Substance of a lecture delivered by Sir T. W. Edgeworth David, K.B.E. F.R.S., before the Geological Society of London on March 29. folded in pre-Oligocene time. Eocene marine deposits are mostly wanting except, perhaps, in New Guinea, but the Winton series may be partly Eocene.

Oligocene time was one of very extensive peneplanation, which was prolonged into the Miocene, and in places into early Pliocene time. A rock-crust, or 'petroderm' ('Hartrinde' of Walther) formed over the more arid parts of this peneplain. Marine transgressions occurred all along the southern coast of Australia, mostly following on the eruptions of the older basalts.'

In Miocene time there were warm seas with large foraminifera (Lepidocyclina) and reef-forming corals, even in Tasmania. The earliest marsupials are found there in the Miocene beds. Miocene browncoal deposits up to 800 feet thick, formed partly of Fagus and Banksia, occur in Victoria. 'Deep leads' of gold and tin were formed inland. In New Guinea the oil-belt was developed during the Miocene Period.

In Pliocene time the whole peneplain underwent differential movement which was strongest in eastern Australia. Alkaline lavas were erupted from tensional fault-planes in the old peneplain. Epeirogenic uplift (during the 'Kosciusko epoch' of E. C. Andrews) now followed, and became accelerated in a late Pliocene epoch. The Rift Valley of Australia formed mostly during this uplift. This later movement was accompanied by widespread eruptions of basalts with some andesites. The Great Barrier Reef was already forming, and possibly commenced to develop even earlier.

The southern edge of the Lake Eyre peneplain became tilted northwards, and that of Western Australia eastwards, bringing about interior drainage and local aridity. The Pleistocene ice-age followed, together with a pluvial epoch, when Lake Eyre once more drained seawards. Crocodiles and gigantic marsupials were then abundant in Central Australia. The Tasmanian aborigines arrived in Tasmania by way of the Malay Bridge, possibly during a eustatic negative movement of the sea. As the Ice Age ended, the sea-level rose, drowning the coastal valleys. The rainfall decreased. Lastly, the Australian aborigines 
arrived, perhaps bringing with them the dingo. In the last few thousands of years the sea-level has fallen by about I 5 feet.

The salient features in the tectonic structure were briefly discussed, with especial reference to Suess's views as to the arrangement of the Australian arcs, and the physiographic features, chiefly with reference to the phenomena of arid erosion. The origin of the inland sand-hills of Central Australia is attributed to the disintegration of the widespread Permo-Carboniferous sandstones, for the later seas of that period transgressed over large areas of-Australia, possibly in part through a eustatic rise of sea-level following on the melting of the great Permo-Carboniferous ice-sheets.

\section{Ventilation and Comfort.}

THE Medical Research Council has published a report on the "Methods of Investigating Ventilation and its Effecis," by H. M. Vernon and others (Special Report Series, No. Ioo: Methods of Investigating Ventilation and its Effects. London: H.M. Stationery Office, I926, 2s. net). Part I contains descriptions of two new instruments for the measurement of variations $(a)$ in the velocity and $(b)$ in the temperature of air currents. For the former purpose a new form of hot-wire anemometer was constructed which is very sensitive to changes of air velocity, while influenced little by changes in temperature. For the latter purpose a suitable thermopile was devised which was unaffected by changes in velocity. The combined use of these two instruments has thrown further light on the relative importance of temperature and air movement in ventilation. In Part 2 the results of a further calibration of Leonard Hill's kata-thermometer are given, which allow low-air velocities found in ordinary rooms to be measured with far greater accuracy.

Part 3 consists of an investigation of the extent to which objective indications of the kata-thermometer correspond with actual sensations of comfort. Acclimatisation is shown to have an important influence. It is concluded that the cooling power of 6 , fixed as the minimum for sedentary workers in Great Britain by Leonard Hill, may reasonably be 5 for people acclimatised to summer weather, and 7 for people acclimatised to winter weather. "It was found that the various degrees of 'stagnancy' experienced in factory air were due to differences in the air temperature, whilst the various degrees of 'freshness' were due chiefly to differences in air velocity. The cooling power of the kata-thermometer combines these two variables better than any other known measure, and the correlation ratio of cooling power on air sensation was found to be 703 in summer and '790 in winter."

In Part 4 , Dr. Vernon has studied the rate of cooling of the human body, as shown by fall of mouth and rectal temperatures, naked and clothed, after being warmed up by previous exercise, and has in this way thrown further light on the relative importance of air temperature, clothing, and air movements The results tend to show that in order to induce cooling of men engaged in hot and heavy work, it is of most importance to reduce temperature and next clothing, small increase of velocity of air having comparatively little effect.

Work now in progress in the new wind tunnel built at the National Institute for Medical Research shows, however, that velocity can have a very great effect on warmly clad men, when it is sufficient to drive air through and so ventilate the clothing. By means of wind sufficient to evaporate the sweat effectively, men can be kept much more comfortable, and will in consequence work better, in hot atmospheres.

$$
\text { NO. 2947, VOL. I I } 7 \text { ] }
$$

\section{University and Educational Intelligence.}

LONDON.-A University chair of bacteriology and immunology, tenable at the London School of Hygiene and Tropical Medicine, and a University chair of epidemiology and vital statistics, tenable at the London School of Hygiene and Tropical Medicine, have been instituted.

The following courses of free public lectures are announced: "The Influence of Water on Vital Processes," by Prof. J. B. Collingwood, at University College, on April 26, May 3, Io, I7, 24, and $3 \mathrm{r}$, at 5.30 ; "The Integration of the Circulation," by Prof. R. J. S. McDowall, at King's College, on April 27, May 4, II, and I8, at 4.30; and "The Nature and Functions of the Fasciæe of the Human Body," by Prof. J. Kay Jamieson, at King's College, on April 3o, May 7 and I4, at 5.30.

Applications for grants from the Dixon Fund for assisting scientific investigations, accompanied by the names and addresses of two references, must be made to the Academic Registrar, University of London, South Kensington, S.W.7, before May I5, and those for grants from the Thomas Smythe Hughes Fund for assisting Medical Research, accompanied by the names and addresses of two references, not later than June ${ }_{5} 5$.

Applications are invited by the Ministry of Agriculture and Fisheries for not more than five agricultural scholarships tenable for two years and annually of the value of not more than 2ool., plus, possibly, extra allowances for travelling and subsistence whilst the scholars are abroad. The application form, A.r $89 /$ T.E., must be returned to the Secretary of the Ministry, to Whitehall Place, S.W.I, by June $3^{\circ}$ at latest.

IT was stated in the House of Commons last week by Lord Eustace Percy, President of the Board of Education, that the Government is in general agreement with the recommendations of the Departmental Committee on the University of London, and that it is proposed to introduce legislation for the purpose of setting up a statutory Commission for the University accordingly.

THE presentation portrait of the late Sir Sydney Russell-Wells, painted by his nephew, Mr. John Wells, R.I., will be unveiled in the staff room of the Dreadnought Hospital, Greenwich, by Sir Humphry Rolleston, Bart., at 3 o'clock on Tuesday, May 4. The portrait, which has been subscribed for by the friends and colleagues of the late Sir Sydney RussellWells, represents Sir Sydney in his robes as ViceChancellor of the University of London. Those desiring to be present at the ceremony may obtain cards of invitation on application to Prof. R. Tanner Hewlett at the Seamen's Hospital, Greenwich.

THE Court of the Worshipful Company of Poulters has agreed to offer a scholarship of $60 l$. per annum for two years tenable at the Harper Adams Agricultural College, for the training of persons to be instructors in the practice and science of poultry husbandry. Candidates must be British-born and not less than sixteen years of age on October I, I926. They must produce satisfactory certificates of character and physical fitness, and should have passed an examination of matriculation standard. The successful candidate will be required to take an approved course of study leading to the National Diploma in Poultry Husbandry. The award will be made on the recommendation of the Principal of the Harper Adams Agricultural College, to whom all inquiries should be addressed. 